\title{
SELECTION AND SCREENING OF SPIRITUOUS YEAST RACE WHEN FERMENTATION OF WORT WITH HIGH CONCENTRATION FROM STARCHY RAW MATERIAL TAKES PLACE
}

\author{
T. Mudrak, A. Kuts, S. Kovalchuk, I. Boiarchuk \\ National University of Food Technologies
}

\begin{tabular}{l}
\multicolumn{1}{c}{ Key words: } \\
Alcoholic yeast \\
Screening \\
Selection \\
Highly concentrated mush \\
Dry matter \\
Fermentation \\
\hline
\end{tabular}

Article history:

Received 12.03.2018

Received in revised form 03.04.2018

Accepted 19.04.2018

Corresponding author:

T. Mudrak

E-mail:

mudrak_t_o@ukr.net

\begin{abstract}
The developments devoted to energy and resourcesaving technologies are among the promising areas of development of the alcohol industry. One of the ways to intensify the process of fermentation of wort is to increase the concentration of dry matter. However, there is a number of problems associated with the physiological characteristics of yeast in fermentation of the wort of high concentrations. Therefore, the question about the selection of new races which are able to the maximally full fermentation of carbohydrates of highly concentrated wort arises.

The production experience confirms that in the conditions of thermo-enzymatic treatment of grain raw materials using concentrated enzyme preparations and bard filtrate at the stage of preparation, the selection work should be aimed at obtaining yeast, able to ferment the wort not only at high concentrations, but also at high temperatures and acidity.

The purpose of our work was to conduct a comparative analysis of industrial and new selected rations of alcoholic yeast and to carry out screening of yeast with thermotolerant and osmophilic properties. A new strain of yeast was selected through multi-stage selection, capable to withstand high osmotic pressure up to $36 \%$ DM (dry matter), and has biosynthetic properties directed towards ethanol (14-17\%) and acidity. Screening of alcoholic yeast was carried out in order to select races for the fermentation of high concentrations of wort.
\end{abstract}

For the fermentation of the wort of high concentrations there were used races of Saccharomyces cerevisiae XII, K81 , DO-11, DO-16. The influence of dry matter concentration in the range of $17-32 \%$, temperature $-30-38^{\circ} \mathrm{C}, \mathrm{pH}-$ $2,5-5,0$ was investigated.

Implementation of selected yeast race can not only increase profitability but also quantity of alcohol and provide hight level of fermentation of mash with high acidity and concentration.

DOI: $10.24263 / 2225-2924-2018-24-2-26$ 


\title{
СЕЛЕКЦІЯ ТА СКРИНІНГ РАС СПИРТОВИХ ДРІЖДЖІВ ПРИ ЗБРОДЖУВАННІ ВИСОКОНЦЕНТРОВАНОГО СУСЛА 3 КРОХМАЛЕВМІСНОЇ СИРОВИНИ
}

\author{
Т.О. Мудрак, А.М. Куц, С.С. Ковальчук, Я.А. Боярчук \\ Національний університет харчових технологій
}

Серед перспективних напрямків розвитку спиртової галузі представлені розробки, присвячені енерго- та ресурсозберігаючим технологіям. Одним із способів інтенсифікаиії прочесів зброджування сусла є підвищення конщентрачії сухих речовин. Проте при зброджуванні сусла високих концентрацій виникає ряд проблем, пов'язаних з фізіологічними особливостями дріжджів. Тому постає питання селекції нових рас, здатних до максимально повного зброджування вуглеводів високониентрованого сусла.

Виробничий досвід підтверджує, що в умовах термоферментативної обробки зернової сировини з використанням концентрованих ферментних препаратів і фільтрату барди на стадії приготування замісів селекційна робота повинна бути направлена на отримання дріжджів, здатних зброджувати не тільки сусло при високих концентраціях, але й при високих температурах та кислотності.

Метою дослідження було проведення порівняльної характеристики промислових $і$ нових селекціонованих рас спиртових дріжджів $і$ здійснення скринінгу дріжджів з термотолерантними й осмофільними властивостями та кислотності.

У результаті проведених досліджень селекціоновано новий штам дріжджів иляхом багатоступеневої селекиії, який здатен витримувати високий осмотичний тиск до $36 \%$ (сухих речовин) СР і має направлені біосинтетичні властивості стосовно етанолу (14-17\%) та кислотності. Проведено скринінг спиртових дріжджів з метою підбору раси для зброджування сусла високих концентрацій.

Для зброджування сусла високих конщентраиій використані раси Saccharomyces cerevisiae XII, K-81, ДО-11, ДО-16. Досліджено вплив концентрації сухих речовин в інтервалі 17-32\%, при температурі-30-38 $\mathrm{C}, \mathrm{pH}-2,5-5,0$.

Впровадження селекиіонованої раси дріжджів дасть змогу не тільки підвищити рентабельність виробництва, а й вихід спирту та забезпечити високу зброджуваність сусла при високій його кислотності й концентрачії.

Ключові слова: спиртові дріжджі, скринінг, селекція, високонцентроване сусло, сухі речовини, зброджування.

Постановка проблеми. Важливим напрямком розвитку спиртової галузі $\epsilon$ підвищення ефективності виробництва, виходу та якісних показників цільового продукту, зниження собівартості [1].

Розробка біокаталітичних технологій приготування і зброджування концентрованого зернового сусла 3 використанням фізіологічно активних рас дріжджів дає змогу збільшити ефективність переробки сільськогосподарської 
сировини на спирт технологічним шляхом, знизити утворення відходів виробництва, в тому числі післяспиртової барди.

Огляд останніх досліджень і публікацій. Розробка інноваційних технологій $з$ метою інтенсифікації процесу зброджування викликає необхідність виділення більш фізіологічно активних рас дріжджів, а також впровадження різних технологічних прийомів і способів, які забезпечують підвищення продуктивності дріжджових клітин [2].

Основні показники якості спиртових дріжджів:

- висока бродильна здатність;

- здатність до синтезу етанолу з пониженим утворенням побічних продуктів;

- стійкість до продуктів обміну, підвищених концентрацій спирту;

- витримувати високі концентрації сухих речовин, температури та кислотності.

Збільшення виробничих потужностей шляхом установки додаткових ємностей нерентабельне. Підвищити ефективність роботи бродильного відділення можна за рахунок використання якісних рас дріжджів. Дріжджі - мікроорганізми, здатні змінювати технологічні властивості, тому їх вибір повинен базуватись на раціональному скринінгу раси, стійкої до несприятливих умов 3 термотолерантними й осмофільними властивостями [3; 4].

Зброджування високонцентрованого сусла $є$ одним із способів інтенсифікації виробництва спирту [5].

Ефективність процесу одержання спирту багато в чому залежить від рас дрідждів, фізико-хімічних умов виробництва: температури, $\mathrm{pH}$, концентрації сухих речовин, складових показників сусла [6-8].

Виробничий досвід підтверджує, що в умовах термоферментативної обробки зернової сировини 3 використанням концентрованих ферментних препаратів і фільтрату барди на стадії приготування замісів селекційна робота повинна бути направлена на отримання дріжджів, спроможних зброджувати сусло не тільки високих концентрацій, але й при високих температурах і кислотності. На сьогодні в спиртовій галузі України використовують термотолерантні й осмофільні раси дріжджів Saccharomyces cerevisiae K-81, ДО-11 тощо.

Мета статті: проведення порівняльної характеристики промислових i нових селекціонованих рас спиртових дріжджів та здійснення їх скринінгу 3 термотолерантними й осмофільними властивостями, дослідження впливу різних рас дріжджів на зброджування сусла високої концентрації із зернової сировини, дослідження накопичення дріжджових клітин залежно від раси 3 метою економії та підвищення виходу кінцевого продукту — етилового спирту.

Матеріали і методи. У процесі досліджень використовували помели зерна кукурудзи з дисперсністю 100\% проходу через сито з діаметром отворів 1 мм. Для приготування сусла використовували зерно кукурудзи крохмалистістю $69,5 \%$.

Зброджували сусло расами дріжджів Saccharomyces cerevisiae XII, K-81, ДО-11, ДО-16. Крохмалистість вихідного зерна визначали за методом Еверса [9]. Вологість зерна 3 за методом підсушуванням до постійної маси [9]. 
Гранулометричний склад помелу зерна визначали методом розсіву на металевих і капронових ситах [9]. Концентрацію сухих речовин за допомогою цукроміру та на рефрактометрі [9].

Приготування сусла вели за низькотемпературною схемою розварювання при температурі $85-92^{\circ} \mathrm{C}$ з використанням концентрованих ферментних препаратів $\alpha$-амілази тривалістю 3 години. Розріджену масу охолоджували до температури $50-55^{\circ} \mathrm{C}$ і оцукрювали глюкоамілазою протягом 0,5 години. Для приготування дріжджів сусло підкисляли сірчаною кислотою до кислотності 0,5-0,6 град. Культивування дріжджів проводили при температурі $30-32^{\circ} \mathrm{C}$. Для розрідження й оцукрення замісів використовували ферментні препарати фірми «Даніско», Бельгія: як $\alpha$-амілази - Амілекс 4Т, глюкоамілази - Діазім TGA.

Фізіологічний стан дріжджових клітин визначали за забарвленням дріжджової клітини розчином Люголя, а вміст мертвих клітин - 3 метиленовим синім, кількість дріжджів, що брунькуються, та їх накопичення - в камері Горяєва.

У лабораторних умовах чисті культури досліджуваних дріжджів 3 косяку пересівали в пробірку із стерильним пивним суслом концентрацією 9- $10 \% \mathrm{CP}$ та зброджували його протягом 24 годин при температурі $30^{\circ} \mathrm{C}$. Після цього вміст пробірки стерильно переносили у колбу, яка містить 200 мл стерильного сусла та зброджували протягом 24 годин, бражку центрифугували, осад промивали фізрозчином і використовували для зброджування сусла.

У лабораторних умовах сусло зброджували за методом «бродильної проби» в конічних колбах з сірчанокислотними затворами у термостаті. Динаміку виділення двоокису вуглецю контролювали ваговим методом [9].

У зрілій бражці рН визначали електрометричним методом, вміст етанолу в зрілій бражці пікнометричним методом, незброджені та спирторозчинні вуглеводи, нерозчинний крохмаль і декстрини - фотоелектроколориметричним методом 3 антроновим реактивом [9].

Результати і обговорення. Для розробки технології зброджування сусла 3 крохмалевмісної сировини було селекціоновано новий штам дріжджів шляхом багатоступеневої селекції, який здатен витримувати високий осмотичний тиск до 36\% (сухих речовин) СР і має направлені біосинтетичні властивості стосовно етанолу та витримує високу температуру й кислотність сусла.

На першому етапі були проведені дослідження з визначення оптимальної концентрації сусла при зброджуванні селекціонованим штамом дріжджів ДО-16 (табл. 1).

Таблиия 1. Вплив концентрації сусла із кукурудзи (СР) на показники дозрілої бражки при зброджуванні осмофільним штамом дріжджів ДО-16

\begin{tabular}{|c|c|c|c|c|c|}
\hline \multirow{2}{*}{ Показники зрілої бражки } & \multicolumn{5}{|c|}{ Концентрація сухих речовин, \% } \\
\cline { 2 - 6 } & 17 & 20 & 26 & 28 & 32 \\
\hline 1 & 2 & 3 & 4 & 5 & 6 \\
\hline Величина рН & 4,8 & 4,95 & 4,95 & 5,0 & 4,98 \\
\hline Кислотність, град & 0,44 & 0,5 & 0,5 & 0,5 & 0,49 \\
\hline
\end{tabular}


Продовження табл. 1

\begin{tabular}{|c|c|c|c|c|c|}
\hline 1 & 2 & 3 & 4 & 5 & 6 \\
\hline Концентрація спирту, \% об. & 8,9 & 10,65 & 13,45 & 14,91 & 16,70 \\
\hline СО $_{2}$, г/200 см & 17,75 & 18,95 & 20,36 & 21,75 & 22,96 \\
\hline $\begin{array}{c}\text { Вміст незброджених } \\
\text { вуглеводів, г/100 см }\end{array}$ & 0,120 & 0,229 & 0,469 & 0,590 & 0,780 \\
\hline $\begin{array}{c}\text { Вміст нерозчинного } \\
\text { крохмалю,г/см }\end{array}$ & 0,08 & 0,09 & 0,10 & 0,12 & 0,15 \\
\hline $\begin{array}{c}\text { Накопичення дріжджів, } \\
\text { млн/см }\end{array}$ & 175 & 224 & 298 & 313 & 320 \\
\hline $\begin{array}{c}\text { \% мертвих клітин } \\
\text { Вихід спирту з 1 т умовного } \\
\text { крохмалю, дал }\end{array}$ & 2,8 & 9,6 & 18,4 & 19,4 & 20,8 \\
\hline
\end{tabular}

При зброджуванні готували сусло 3 допустимою концентрацією - 17, 20 , $26,28,32 \% \mathrm{CP}$.

Із наведених у табл. 1 даних видно, що при зброджуванні сусла концентрацією $17,20,26 \%$ СР основні показники зрілих бражок були на рівні регламентованих. 3 підвищенням концентрації сусла до 28 та $32 \%$ СР ці показники зростають. Так, вміст зброджуваних вуглеводів зріс з 0,449 до 0,780 г/100, а нерозчинного крохмалю - 3 0,10 до 0,15 г/100 г бражки відповідно. Концентрація спирту підвищилася з 313,45 до $16,70 \%$ об.

Але при концентрації 28\% СР втрати з незброджуваними вуглеводами не перевищують $2,85 \%$ щодо введеного на зброджування і не зменшують нормативного виходу спирту. Більш істотне збільшення кількості зброджуваних вуглеводів і втрат при виході спирту спостерігається при концентрації $32 \% \mathrm{CP}$.

На другому етапі були проведені дослідження з скринінгу рас спиртових дріжджів. Для зброджування високої концентрації застосовували раси, які використовуються на спиртових заводах Saccharomyces cerevisiae XII, K-81, ДО-11, а також селекціоновану расу ДО-16. Для зброджування використовували сусло концентраціями $17,20,26,28,32 \% \mathrm{CP}$.

Таблиця 2. Показники зброджування сусла різними культурами дріжджів

\begin{tabular}{|c|c|c|c|c|c|c|c|}
\hline \multirow[b]{2}{*}{ № } & \multirow[b]{2}{*}{$\begin{array}{c}\text { Раса } \\
\text { дріжджів }\end{array}$} & \multirow[b]{2}{*}{$\mathrm{CP}, \%$} & \multicolumn{5}{|c|}{ Показники зрілої бражки } \\
\hline & & & $\mathrm{pH}$ & $\begin{array}{l}\text { Кислотні } \\
\text { сть, град }\end{array}$ & $\begin{array}{c}\text { Вміст } \\
\text { етанолу, } \\
\text { \% об. }\end{array}$ & $\begin{array}{c}\text { Вміст } \\
\text { незброджених } \\
\text { вуглеводів, } \\
\text { г/100 см}{ }^{3}\end{array}$ & $\begin{array}{c}\text { Вміст } \\
\text { нерозчинного } \\
\text { крохмалю, } \\
\text { г/100 cм }\end{array}$ \\
\hline 1 & 2 & 3 & 4 & 5 & 6 & 7 & 8 \\
\hline \multirow{5}{*}{1} & \multirow{5}{*}{ Paca XII } & 17 & 4,80 & 0,49 & 8,00 & 0,15 & 0,08 \\
\hline & & 20 & 4,75 & 0,49 & 10,50 & 0,34 & 0,10 \\
\hline & & 26 & 4,75 & 0,49 & 12,80 & 0,55 & 0,12 \\
\hline & & 28 & 4,95 & 0,49 & 12,40 & 0,90 & 0,15 \\
\hline & & 32 & 4,95 & 0,48 & 12,80 & 1,80 & 0,17 \\
\hline \multirow{5}{*}{2} & \multirow{5}{*}{ Paca K-81 } & 17 & 4,75 & 0,49 & 8,55 & 0,14 & 0,08 \\
\hline & & 20 & 4,80 & 0,50 & 10,65 & 0,32 & 0,09 \\
\hline & & 26 & 4,90 & 0,50 & 13,40 & 0,39 & 0,12 \\
\hline & & 28 & 4,90 & 0,50 & 14,05 & 0,60 & 0,15 \\
\hline & & 32 & 4,75 & 0,49 & 14,08 & 0,97 & 0,17 \\
\hline
\end{tabular}




\begin{tabular}{|c|c|c|c|c|c|c|c|}
\hline & & & & & & \multicolumn{2}{|c|}{ Продовження табл. 2} \\
\hline 1 & 2 & 3 & 4 & 5 & 6 & 7 & 8 \\
\hline \multirow{5}{*}{3} & \multirow{5}{*}{ Раса ДО-11 } & 17 & 5,00 & 0,49 & 8,50 & 0,14 & 0,08 \\
\hline & & 20 & 4,95 & 0,48 & 10,45 & 0,32 & 0,09 \\
\hline & & 26 & 4,60 & 0,48 & 13,10 & 0,50 & 0,12 \\
\hline & & 28 & 5,10 & 0,48 & 14,00 & 0,61 & 0,16 \\
\hline & & 32 & 5,50 & 0,49 & 15,50 & 0,87 & 0,16 \\
\hline \multirow{5}{*}{4} & \multirow{5}{*}{ Раса ДО-16 } & 17 & 4,75 & 0,49 & 8,55 & 0,12 & 0,08 \\
\hline & & 20 & 4,95 & 0,48 & 10,45 & 0,32 & 0,09 \\
\hline & & 26 & 4,90 & 0,49 & 13,45 & 0,29 & 0,10 \\
\hline & & 28 & 4,90 & 0,50 & 15,40 & 0,40 & 0,12 \\
\hline & & 32 & 4,75 & 0,50 & 16,20 & 0,69 & 0,15 \\
\hline
\end{tabular}

Наведені в табл. 2 дані свідчать, що всі досліджені культури при концентрації сусла 17-20\% СР синтезують спирт практично на одному рівні - 8-8,5 та 10,5-10,65\% об. відповідно. 3 підвищенням концентрації сусла до $26 \%$ СР кількість спирту, синтезованого культурами дріжджів К-81 та ДО-11 збільшується відповідно з 10,65 до 13,4 та 3 10,45 до 13,1\% об. (табл. 2). Осмофільний штам дріжджів Saccharomyces cerevisiae ДО-16 забезпечує найкращу здатність зброджувати сусло високої концентрації і при цьому накопичує до $13,4-16,2 \%$ об. спирту. Побічним критерієм оцінки бродильної активності досліджених дріжджів може бути підвищення кислотності сусла, яка збільшувалась зі зростанням концентрації сусла, особливо при концентрації сусла 28 та $32 \% \mathrm{CP}$.

Результати лабораторних досліджень процесу зброджування сусла високої концентрації з крохмалевмісної сировини новим осмофільним штамом дають підстави рекомендувати його для широкого впровадження на підприємствах галузі, що дасть змогу підвищити іiі ефективність.

Для дослідження нової раси дріжджів проведено порівняння в процесі дріжджегенерування на суслі з кукурудзи концентрацією 24\% СР з різними расами дріжджів (рис. 1). Встановлено що найвища кількість дріжджових клітин накопичена расою Saccharomyces cerevisiae ДО-16 340 млн/см³, що 1,2-1,5 раза вище порівняно з досліджуваними расами.

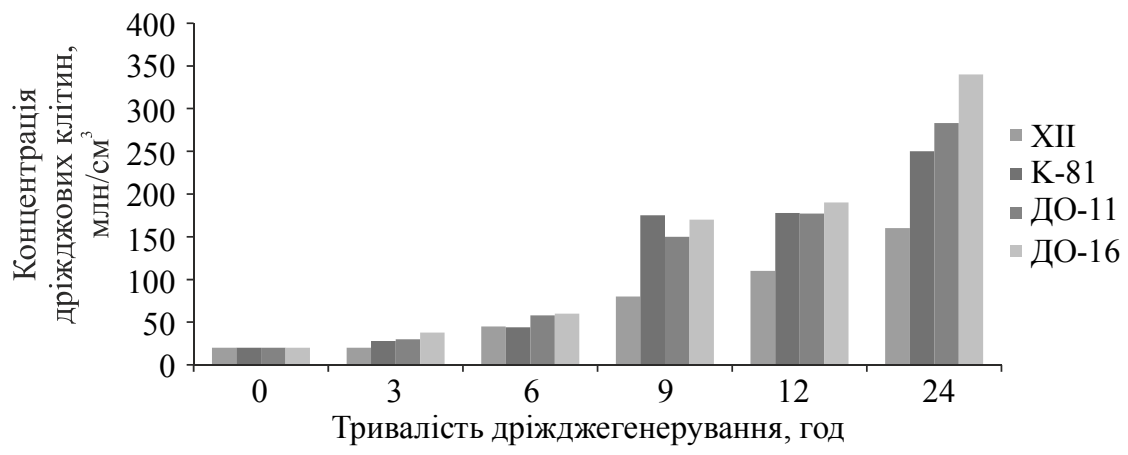

Рис. 1. Показники накопичення дріжджових клітин залежно від раси дріжджів 
Для визначення стійкості досліджуваних рас до високих концентрацій сусла та температури було проведено дріжджегенерування при концентраціях сусла $20 \%$ та $28 \% \mathrm{CP}$, а також при температурі $30,32,35,38^{\circ} \mathrm{C}$. Досліджено, що порівняно з іншими расами ДО-16 здатна витримувати високу концентрацію сусла й температуру (табл. 3).

Встановлено, що найвищі концентрації дріжджових клітин були при температурі $30-32^{\circ} \mathrm{C}$ незалежно від раси та концентрації сусла. 3 підвищенням температури до $35^{\circ} \mathrm{C}$ вміст дріжджових клітин знижувався незалежно від раси дріжджів. Найбільша кількість клітин накопичувалась расою Saccha-

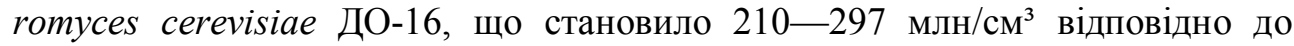
концентрації сусла.

Таблиия 3. Вплив концентрації сусла і температури на процес синтезу дріжджів різними расами дріжджів

\begin{tabular}{|c|c|c|c|c|c|c|c|c|c|}
\hline \multirow{5}{*}{ № 1} & \multirow{5}{*}{$\begin{array}{c}\text { Раса } \\
\text { дріжджів }\end{array}$} & \multicolumn{8}{|c|}{ Концентрація дріжджових клітин млн/см³ } \\
\hline & & \multicolumn{8}{|c|}{ Концентрація сусла СР, \% } \\
\hline & & \multicolumn{4}{|c|}{20} & \multicolumn{4}{|c|}{28} \\
\hline & & \multicolumn{4}{|c|}{ Температура, ${ }^{\circ} \mathrm{C}$} & \multicolumn{4}{|c|}{ Температура, ${ }^{\circ} \mathrm{C}$} \\
\hline & & 30 & 32 & 35 & 38 & 30 & 32 & 35 & 38 \\
\hline 1 & XII & 134 & 95 & 89 & 48 & 115 & 205 & 156 & 65 \\
\hline 2 & K-81 & 131 & 133 & 139 & 55 & 187 & 165 & 149 & 41 \\
\hline 3 & ДО-11 & 172 & 170 & 162 & 57 & 136 & 168 & 125 & 75 \\
\hline 4 & ДО-16 & 185 & 210 & 185 & 60 & 214 & 297 & 192 & 93 \\
\hline
\end{tabular}

У результаті зброджування високонцентрованого сусла відбувається не лише синтез основних і побічних продуктів бродіння, але й високі концентрації органічних кислот. На сьогодні для приготування замісу застосовують фільтрат барди, використання якого також обумовлює зниження кислотності сусла. При цьому важливо, щоб дріжджі були здатні витримувати не тільки високу концентрацію сусла, а й кислотність. Були проведені дослідження 3 визначення стійкості різних рас спиртових дріжджів до хімічного стресу, викликаного високою кислотністю сусла (рис. 2). Сусло підкислювали до зазначених $\mathrm{pH}$ сірчаною кислотою.

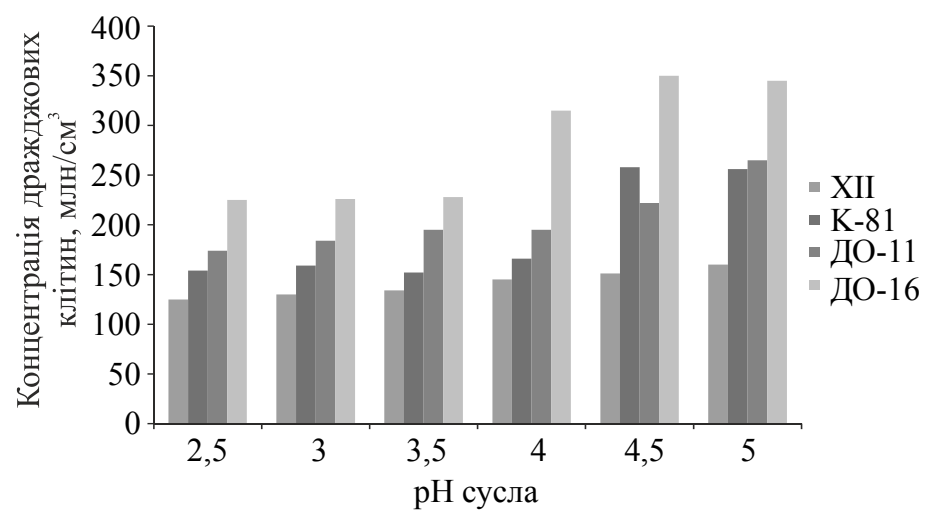

Рис. 2. Вплив рН сусла на дріжджегенерування 
Встановлено що при значеннях $\mathrm{pH}$ 2,5, 3,0, 3,5 у раси Saccharomyces cerevisiae ДО-16 концентрація клітин була вищою в 2,5, 1,8, 1,5, 1,4 раза порівняно 3 досліджуваними расами.

На наступному етапі досліджена динаміка синтезу органічних сполук різних груп, а саме: вищих і ароматичних спиртів, альдегідів, складних естерів у процесі зброджування сусла 3 фіксованою початковою концентрацією $\mathrm{CP}-32 \%$ та заданою температурою бродіння $-30-35^{\circ} \mathrm{C}$.

Залежність концентрації летких органічних сполук у бражних дистилятах пов'язана з регуляторними функціями дріжджових клітин, які значною мірою залежать від раси спиртових дріжджів і технологічних параметрів приготування й зброджування сусла.

За результатами отриманих експериментальних даних за вмістом летких органічних домішок у бражних дистилятах встановлено, що концентрація компонентів, які входять до групи альдегідів при зброджуванні сусла класичною расою ХІІ становила 47,8 мг/дм³ ${ }^{3}$ у раси ДО-16 концентрація цього компоненту знижувалася в 1,6 раза, а у раси ДО-11 зростала майже у 1,2 раза порівняно $з$ расою XII та з расою ДО-16 - в 1,9 раза (табл. 4). При цьому концентрація вищих та ароматичних спиртів при зброджуванні сусла расою XII складала 263,54 мг/дм³, К-81 - 254,66 мг/дм³ ${ }^{3}$ ДО-11 - 262,81 мг/дм ${ }^{3}$, ДО-16 - 235,13 мг/дм³. У динаміці синтезу складних естерів спостерігалася аналогічна тенденція.

Таблиия 4. Вміст летких домішок у бражних дистилятах при зброджуванні сусла різними расами дріжджів

\begin{tabular}{|c|c|c|c|c|c|c|c|c|c|c|c|c|}
\hline \multirow[b]{3}{*}{$\begin{array}{l}\text { № } \\
\Pi / \Pi\end{array}$} & \multirow[b]{3}{*}{$\begin{array}{l}\text { Раса } \\
\text { дріж- } \\
\text { джів }\end{array}$} & \multicolumn{11}{|c|}{ Вміст летких компонентів, мг/ дм } \\
\hline & & \multirow{2}{*}{ 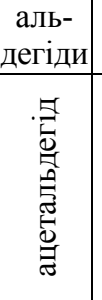 } & \multicolumn{4}{|c|}{ естери } & \multirow{2}{*}{ 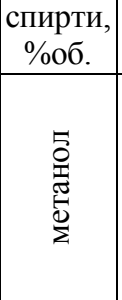 } & \multicolumn{5}{|c|}{ сивушні спирти } \\
\hline & & & 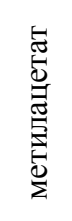 & 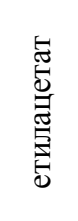 & 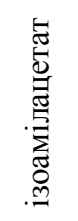 & 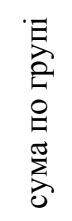 & & 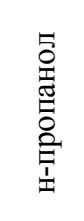 & 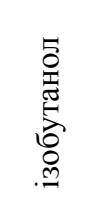 & 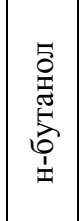 & 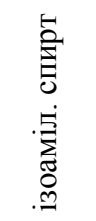 & 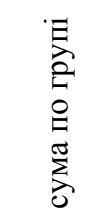 \\
\hline 1 & IIX & 47,8 & 1,15 & 2,02 & 8,77 & 11,9 & 0,0048 & 83,11 & 41,26 & 9,07 & 130,1 & 263,54 \\
\hline 2 & K-81 & 48,6 & 0,93 & 2,15 & 6,54 & 9,62 & 0,005 & 104,5 & 36,29 & 7,97 & 105,9 & 254,66 \\
\hline 3 & ДО-11 & 55,8 & 1,36 & 2,12 & 1,32 & 4,80 & 0,0045 & 75,06 & 40,44 & 1,01 & 146,3 & 262,81 \\
\hline 4 & ДО-16 & 29,6 & 1,09 & 1,87 & 1,05 & 4,01 & 0,0044 & 71,06 & 36,31 & 8,56 & 119,2 & 235,13 \\
\hline
\end{tabular}

\section{Висновки}

Отже, pacy Saccharomyces cerevisiae ДО-16 можна рекомендувати для промислового застосування при зброджуванні високонцентрованого сусла, тому що вона більш стійка до таких факторів, як кислостійкість, осмотичний тиск, високі концентрації етанолу в бражках, термостійкість порівняно 3 іншими расами. Застосування нової раси дасть змогу інтенсифікувати виробництво спирту при зброджуванні сусла високих концентрацій.

Для зброджування сусла із кукурудзи концентрацією $32 \%$ СР при заданій температурі бродіння $30-35^{\circ} \mathrm{C}$ раціональним прийомом у технології $\epsilon$ 
використання раси ДО-16, що підтверджується мінімальними концентраціями різних груп летких органічних домішок і підвищеним вмістом етилового спирту в бражних дистилятах.

\section{Лiтература}

1. Шиян П.Л. Іноваційні технології спиртової промисловості. Теорія і практика: монографія / П.Л. Шиян, В.В. Сосницький, С.Т. Олінійчук. - Київ : Асканія 2009.— 424 с.

2. Римарев Л.В. Состояние и перспективы развития современных технологий в спиртовом производстве // Производство спирта и ликероводочных изделий. - 2005. - № 2. C. $4-6$.

3. Araque Edgardo, Parra Carolina, Rodríguez Manuel, Freer Juanita, Baeza Jaime Selection of thermotolerant yeast strains Saccharomyces cerevisiae for bioethanol production // Enzyme and Microbial Technology. —August 2008.-Volume 43, Issue 2. - P. 120-123. doi.org/10.1016/j.enzmictec.2008.02.007.

4. Левандовський Л.В. Дослідження впливу умов культивування дріжджів на результати спиртового зброджування сусла із зерна / Л.В. Левандовський, А.П. Михайлів // Вісник аграрної науки. - 2010. — № 9. - С. 50-53.

5. Давыденко С.Г. Скрининг штаммов спиртовых дрожжей для сбраживания высококонцентрированного сусла / С.Г. Давыденко, А.С. Устинова, Т.В. Меледина, Н.В. Баракова // Научный журнал НИУ ИТМО. Серия: Процессы и аппараты пищевых производств. 2012. - № 2. - С. 14.

6. Храпова А.В. Скрининг новых штаммов дрожжей, перспективных для получения биомассы / А.В. Храпова, О.Б. Сопрунова // Тезисы докладов. Том I. - Астрахань : Астраханский государственный університет, 2010. - С. 20.

7. Римарева Л.В. Осмофильный штамм спиртових дрожей Saccharomyces cerevisiae 1039 для сбраживания концентрированого зернового сусла / Л.В. Римарева, М.Б. Оверченко, Н.И. Игнатова, Е.М. Серба // Производство спирта и ликероводочных изделий. — 2012. № 3. - C. $6-11$.

8. Олийничук C.T. Зависимость накопления глицерола и сбраживания гидролизатов крохмалсодержащего сырья от концентрации сусла / С.Т. Олийничук, Т.И. Лысак, Л.В. Маринченко // Biotechnologia Acta. - 2015. - T. 8, № 4. - C. 128-134. doi: 10.15407/biotech8.04.128.

9. Полигалина Г.В. Техно-химический контроль производства алкогольных и ликероводочных изделий / Г.В. Полигалина. — Москва : Колос, 1999. — 334 с. 